\title{
POLITICAL FACTORS AND THE EFFICIENCY OF MUNICIPAL EXPENDITURE IN BRAZIL
}

\author{
Ronaldo Seroa da Motta* \\ Ajax Moreira
}

\begin{abstract}
Resumo
Este estudo analisa como fatores políticos e institucionais afetam a eficiência do gasto municipal no provimento do bem estar para a população ao longo da década dos noventa. O modelo adota a abordagem da fronteira de produção estocástica, condicionada por variáveis relacionadas ao custo da provisão dos serviços e os incentivos que afetam a eficiência municipal. O resultado indica que não podemos rejeitar: 1) economias de escala; 2) o efeito da margem de voto no município e do tipo de mandato (primeiro ou segundo) do governador eleito, indicando uma forma de clientelismo; e que 3) a política local e a existência de comitê setoriais não afetam o nível da eficiência do gasto, o que sugere assimetria de informação entre os políticos e os eleitores.
\end{abstract}

Keywords: economia política, eficiencia serviço publico, fronteira estocástica, econometria espacial

\begin{abstract}
This study analyses how political and institutional factors affected the performance of municipalities in improving social welfare in Brazil in the period from 1990 to 2000 . The model adopts a stochastic production frontier, conditioned by variables related to the provision costs of services and those that can affect municipal efficiency. The results indicated that we can not reject:1) economies of scale; 2) the effect of vote margin in the municipality and the type (first or second) of mandate of elected governor, which indicates a form of patronage; and 3) that local politics and the existence of sectorial boards did not affect the level of efficiency for municipal spending, suggesting an asymmetry of information between politics and voters.
\end{abstract}

Keywords: political economy, public service eficiency, stochastic frontier JEL classification: D72, H11, H83

\footnotetext{
* At the Research Institute of Applied Economics (IPEA). Address: Av. Pres. Antonio Cralos 51, 17 anadra, Rio de Janeiro, 20020-010, RJ, Brazil. Email: ajaxmoreira@gmail.com and ronaldo.seroa@anac.gov.br
} 


\section{Introduction}

A social planner should use municipal funds to maximize the quality of life of local residents. In other words, local tax revenues and transfers from the state and federal level should finance the responsibilities of the municipality ${ }^{1}$ to supply basic education, health care and other public services. Elected leaders, though, often have other objectives besides benefiting their constituencies. Municipal management can be affected by local conditions and by the electoral dispute for local offices or the local votes for state and federal offices. Our objective is to investigate whether the electoral dispute and institutional characteristics affect the provision of municipal services. This motivates efforts to estimate the efficiency of municipal management in transforming public funds into services for the population, and explains the sources of this difference.

In this article we propose a measure for the spending inefficiency of Brazilian municipalities during the 1990s and relate this measure to institutional characteristics and electoral dispute, which can alter the conditions and incentives for the supply of public services. To do this we use the stochastic production frontier model, which distinguishes inefficiency and its determinants, and an approach to mitigate the bias due to unobservable factors. It should be clear that in this approach the inefficiency measure is constructed by comparisons among municipalities. Therefore, this is only a relative measure of inefficiency. The non-experimental nature of the data utilized and the possibility that the institutional characteristics and the electoral dispute are determined together with social conditions and public spending limit the scope of our results ${ }^{2}$.

There is an extensive body of literature examining the effect of political and institutional conditions on public expenditure. The initial normative economic literature on public spending, as in Atkinson \& Stiglitz (1980), summarized the social planner's problem into the allocation of resources that maximize social welfare and affect the distributive impact. ${ }^{3}$ Later, median voter models were developed, in which expenditures are electorally decided and decline with the tax contribution of the median voter in total spending. These models resulted in an extensive body of empirical literature, as summarized in Cutler et al. (1993). In contrast, models that describe strategies to capture spending by interest groups, as summarized in Peltzam (1993), focus on perceived benefits. ${ }^{4}$ In countries where the median voter receives less income than the median voter, spending would be higher and more aimed at social problems (Meltzer \& Richard 1981). This, however, does not ensure that public spending will be more efficiently utilized and result in reduced inequality,

\footnotetext{
${ }^{1}$ In Brazil, the local administrative unit is the municipality, which is roughly the same as a county, except that it has a single administration, under a mayor and municipal council. Urban municipalities correspond basically to single cities, while rural ones can take in several small towns or villages. The Constitution provides a mechanism for parts of municipalities to split off and form separate units.

${ }^{2}$ With non experimental data it is hard to select valid instruments that permit identifying causality relations.

3 . In the first case, we consider the unweighted sum of the utilities, and in the second, distributive weights can be used.

${ }^{4}$ Strömberg (2006) develops a median voter model with focus on the benefits of interest groups, a model in which spending grows with the median voter's perception of the personal benefit in the total benefit.
} 
since imperfections in the political market affect this process of transforming voter preferences into results.

The literature on the provision of public services uses the theory of industrial organization when the monopoly power that governments have on public spending is politically contested, and thus examines the entry and exit barriers that determine the quality and quantity of services and the extraction of rent. Examples of this approach are Lake \& Baum (2001) and Keefer \& Khemani (2005). The political market is open to competition in democracies, since in this case there is no regulatory barrier to entry. However, the existence of sunk costs (campaign and reputation-building costs) creates barriers that reduce competition. Similarly, the distribution of the costs of voter participation is crucial for core or swing voters to exercise their influence. With a small percentage of voters at low cost, the monopolist rent of the state tends to be captured by these voters.

More recently, the principal-agent model has been considered to explain how competitive the political market is in converting voter preferences into results of public expenditures (for example,Dixit (1996),Dixit (2002);Burgess \& Metcalfe (1999)). Voters' difficulty in observing politicians' performance generates information asymmetry for voters that reduces political competition, and therefore also reduces the incentives politicians have to offer nonexcluding public services.

The asymmetry between politicians and voters is explained as the result of the difficulty of measuring performance - sometimes with multiple dimensions, sometimes with indistinct dimensions,- and inefficiencies in the public service productive chain. Although the voter is the principal, additional agency costs can occur. With the presence of multiple principals between the political decision and the enactment of the service, for example, distinct objectives among the spending overseer, doctor and patient of the public health service may exist. Since each principal wants to induce greater effort from the agent, the incentives to efficiency that the agents perceive end up being low and distorting. ${ }^{5}$ In the literature, incentives have been proposed so that agents' efforts maximize the combined payoff of the multiple principals, and thus avoid inefficiencies above the normal agency costs (see Besley \& Ghatak $(2003))^{6}$, which vary from payment for performance (merit or product) to the freedom of choice of users and to transparency instruments.

This literature lists factors that condition the allocation and efficiency of spending, from the viewpoint of the median voter. In this study, we use those variables to evaluate the varying level of inefficiency of Brazilian municipalities in using the technology of converting public resources into services and seek to explain this heterogeneity.

Empirical literature exists measuring the efficiency of public expenditures in relation to various social and institutional indicators. For example, Afonso et al. (2005) and Afonso \& Aubyn (2005) use nonparametric models and analyze the resulting ranking econometrically regarding income, institutional factors (government transparency, property rights regime and quality of the bureaucracy), trust in politicians and trade openness. They find evidence that only income and institutional variables are significant. Estache et al. (2007),

\footnotetext{
${ }^{5}$ There are externalities, then, that increase the agency cost.

${ }^{6}$ Which range from payment for performance (merit or output) to transparency instruments and sanctions.
} 
using parametric models, also make international comparisons of sectorial spending on energy, transportation and education, models that include quality of bureaucracy and level of corruption as variables. The results by income class indicate that average efficiency diminishes with income and that institutional variables are not significant. Needless to say, such results must be taken with caution due to the well-known econometric problems of cross-country comparisons regarding fixed effects on parameter estimation.

Following a political economy approach, Alston et al. (2007) analyzes the performance of state governments in Brazil, using public expenditures, wealth of politicians and campaign spending as performance measures regressed against political and social control variables. The results of specifications with the interaction among the variables indicate that in nearly all cases political competition and social control are substitutes.

Our study will compare the efficiency of conversion of public expenditures into public services among municipalities and investigate the determinants of these efficiency levels, by examining municipalities that have the same general institutional environment. In doing so, we consider direct measures of the quality of life of the population to evaluate government output and propose an approach to mitigate the effect of unobserved variables for non-panel data.

Section 2 discusses the adopted methodology, Section 3 describes the indicators and Section 4 presents the empirical results. The conclusion is the last section.

\section{Methodologies}

The transformation of spending into the public services that condition the state of public education and health, henceforth, just "state" is a complex and lengthy process that depends on the initial state, the volume of expenditures and the efficiency with which these are made. This efficiency of spending, in turn, depends on the relation between the benefit and cost of the effort to increase administrative effectiveness. Hence, the heterogeneity of this effectiveness among municipal governments can be explained both by the incentives that public administrators perceive to try to be more efficient and by local supply conditions, which alter the marginal cost of this effort. The availability of data delimits the interpretation of the results. We measure the social conditions at the start and end of the decade, and consider the real per capita expenditures made during the decade. Therefore, the inefficiency measure refers to a municipal characteristic that is in some form shared by all three municipal governments in this period ${ }^{7}$. This approach has the advantage of considering the ultimate purpose of public spending, and the disadvantage of indirectly measuring the performance of government management. This municipal characteristic can perhaps be rationalized by arguing that the public bureaucracy is fairly stable, as are the population/voters.

The state of the population is the result of multiple actions of the municipal government, some of which can affect the result although not directly related to the provision of services. We assess the combined performance of the administration of each municipality (combined in the sense that we are

\footnotetext{
${ }^{7}$ Municipal elections (for mayor and city council) are held every four years, offset with elections for president, governors and national and state legislators, also held every four years. In the study period, there were municipal elections in 1992, 1996 and 2000.
} 
considering the activities and also all the governments in the 1990s). Since the allocation of resources among functions is an endogenous process, we specified the production function as having multiple interdependent outputs generated by a single input, represented by total budget spending. With this specification it is useful to define the model as a production possibility frontier that determines per capita spending $(g)$, given the measure of the state $S$ and given a level of municipal inefficiency $(u)$, in the form $g, S, x, z, u{ }^{8}$

This relation is conditioned by 2 types of variables: 1$)$ related to the cost of supplying services and that are not under control of the mayor $(x)$; and 2 ) that affect efficiency $(z)$.

\subsection{Model}

The factors affecting the cost of service considered are the population's demographic conditions, the municipality's degree of fragmentation and favouritism in receiving transfers from the state ${ }^{9}$. Favouritism of state governments can provide additional funds not observed in the public accounts (in a form of patronage) and reduce the mayor's cost of attaining the same level of service to the people. The demographic conditions, concentration of population in the urban area, its age profile and the size of municipalities alter the supply cost, due to the scale returns, access cost and type of service demanded.

The incentive to efficient municipal administration depends on the degree of political competition, the population's interest in participating in decisions and the mayor's profile. In municipalities with greater political competition for mayor or councilors, the mayor's effort, coeteris paribus, tends to be greater and might explain a greater level of efficiency. When a greater portion of revenues come from transfers, on the other hand, there can be an incentive to moral hazard by leaders, and hence inefficiency.

A better-informed electorate can heighten demand for efficient government. The characteristics of municipal administration that affect the cost of providing services can, however, give more or less transparency to performance when there are sectorial advisory boards - education and health - or outsourced government services and computerized processes. We consider as factors that condition efficiency those that directly affect the electoral performance of the mayor or depend on his or her direct action.

However, public services have a cost to maintain the level of the social indicators $(S)$ and an additional cost to promote their improvement (see the list of $S$ in the appendix). With the available information it was not possible to identify these two processes. This suggests that the specification of the technology is ambiguous. If the most important element is to maintain a particular service, the most suitable specification is the state measured by the average value $(S 1+S 0)$; if the most important element is to promote improvement, the best specification is the variation $(S 1-S 0)$; and if the two are equally important, the unrestricted specification is most suitable $(S 1, S 0)$.

The result of supplying municipal services, measured by social indicators, depends on implementing permanent policies that have long maturation horizons. In line with this, we considered average budget spending per inhabitant

\footnotetext{
${ }^{8}$ Or efficiency if signal is changed.

${ }^{9}$ For the sake of simplicity, we consider only the effect of the competition by the state government. The competition by the federal government is often intermediated by the state government, and the results of the two government levels are correlated.
} 
during the analyzed period and the population state at its start and end, obtained from the 1991 and 2000 Demographic Censuses.

As mentioned before, the proposed model assumes that the municipal administration "produces" the population's state $S$, making a per capita expenditure $g$ (measured in logarithms), with the cost-conditioning factors measured by $x$, and the efficiency incentives measured by $z$. We assume it is impossible to identify the relation between spending on the various municipal service provision units and their results, so that it is only possible to measure the relation between the production possibility surface, $S \beta$, and the log of total per capita spending, $g$.

This $\mathrm{S} \beta-g$ relation is then explained by two groups of observed conditional variables: 1$)$ the cost of supply $(x)$; and 2) the efficiency $(z)$ of management; and two stochastic terms: 1) the distance from the production frontier $(u)$, which is identified with the asymmetric form of its distribution; and 2) a random term. The asymmetry is induced by the existence of a frontier that increases the chance that the agents are near it. Naturally, it is an empirical question to verify whether the unobserved component is asymmetric, and thus whether this model can be estimated with the data sample under study. This model is known in the literature as the stochastic frontier production model (see Coelli (1996)).

The determinants of management efficiency $(z)$ can be incorporated into the model according to two descriptions for the form of inserting the $x$ variables in the model, described with the models indicated below. Model (a) assumes $x$ and $z$ are correlated and the frontier is homogeneous. For model (b) $z$ is independent and the frontier is heterogeneous, varying with $(\delta z)$. The equations below describe these cases.

Homogeneous:

$$
g=S \beta-x \gamma+\delta z-u+e, \quad e \sim N\left(0, \sigma^{2}\right), \quad u \sim E\left(\delta_{0}\right)
$$

Heterogeneous:

$$
g=S \beta-x \gamma-u+e, \quad e \sim N\left(0, \sigma^{2}\right), \quad u \sim E\left(\delta_{z}\right)
$$

\subsection{Mitigating the bias of unobservable factors}

The bias due to unobservable or omitted variables is a critical question in identifying a variable's effect in empirical tests. It may be that relevant unobservable quantities are related to the variables of interest, leading to undue attribution of explanatory power and mistaken conclusions. This question is hard to resolve, precisely because it involves unobservable factors. The usual approach in the literature to mitigate this bias is to use a fixed-effects model, which can be estimated when panel data is available. The characteristics of the problem addressed here - long maturation of social processes and the discrepancy between the dates of elections and of census data collection ${ }^{10}-$ only permit one observation per municipality at this moment, making the usual approach impossible. Instead of the fixed-effects model, which eliminates the bias of omitted variables that are stable in time, we propose this approach that eliminates the bias of omitted variables that are stable in space.

\footnotetext{
${ }^{10}$ The spending data are annual, but the social indicators are only available for the census years, 1991 and 2000
} 
In the model $y \mid x$, when there is a unobserved variable $z$ correlated with $x$, and $y$ depends on $x$ and $z$, the effect of $z$ is attributed to $x$. This is a difficult question that is mitigated by formulating hypotheses about the characteristics of the omitted variables. A usual approach with panel data is to suppose that $z$ is constant for each $(m)$ or has a temporal trend or is steady such that $\left(\Delta z_{m}=0\right)$ or $\left(\Delta Z_{m}=u z_{m}\right)$, in which case the model estimated with fixed effect in the spatial dimension $(m)$ eliminates the effect of $z$ when $u z$ is independent of $y$. Variables of this type generally vary smoothly in time, for example, geographic and climatale or some economic and social conditions.

In this work the social conditions are only observed in 1991 and 2000 and are correlated with the flow of annual expenditures, which makes a temporal identification with $\Delta z_{m}$ impossible. In this case, the effect of the variable $z$ can be eliminated when $z$ has a spatial trend. The spatial trend is the smooth variation of a quantity over space, either because the physical medium does not jump or because economic and social processes propagate to neighbouring regions. Below we present the rationale behind these two approaches.

$$
y=\beta x+\gamma z+e .
$$

Temporal Hypothesis: if $z$ does not depends on time $(\Delta z=0)$ or has a temporal trend $\left(\Delta z=z-z_{-1}=u z, u z \sim N\left(0, \sigma^{2}\right), u z \perp y\right)$, then the operator $\Delta$ eliminates the effect of $z$.

$$
\Delta y=\beta \Delta x+\gamma \Delta z+\Delta e=\beta \Delta x+e^{*}
$$

Spatial Hypothesis: if $z$ has a spatial trend $\left(\Delta^{w} z=z-W z=u_{w}, u_{w} \sim N\left(0, \sigma^{2}\right)\right.$, $\left.u_{w} \perp y\right)$, then the operator $\left(\Delta^{w}\right)$ eliminates the effect of $z$. Where $W$ is a neighbourhood matrix ${ }^{11}$ and $W z$ is the local mean of $z$

$$
\Delta^{w} y=\beta \Delta^{w} x+\gamma \Delta^{w} z+\Delta^{w} e=\beta \Delta^{w} x+e *
$$

The two constructions have advantages and limitations; in both cases the hypothesis of independence cannot be tested since $z$ is not observed, but in the case of the temporal difference, the robustness of this hypothesis can be evaluated when one has samples with more than two observations in time. In contrast, the spatial difference assumes spatial trends capture the selection bias of non-observables, a hypothesis that tends to be more realistic when the units are smaller and more mutually homogenous.

In the two cases, the model with the transformed variable generates the unobserved terms of the stochastic frontier model, distance from the frontier and random term $(u, e)$ also transformed. Thus, the asymmetric term of the model with the transformed variables is the deviation of the distance from the frontier. In the case of the temporal difference, if inefficiency is an idiosyncratic property of the unit, the transformed model eliminates this effect, which means that in this case the error loses the asymmetry property. In contrast, in the case of spatial difference, if the inefficiency is idiosyncratic and thus does not present a spatial trend, the asymmetric term is preserved. In this case, the asymmetric term measures the deviation of the distance in relation to the mean distance of the neighbours and it becomes an empirical question to verify whether the asymmetry property is preserved.

\footnotetext{
${ }^{11} W(i, j)=-1 / n(i)$ any time $i$ is a neighbor of $j$, and $n(i)$ is the number of neighbors of $i$.
} 


\section{ELectoral and institutional indicators}

The direct investments and expenditures of the state and federal governments benefit the people of the municipalities. These outlays, made according to the interest of the governor, benefit different municipalities differently, improving the population's state. These outlays are not computed in the municipal budget, and for this reason they can be seen as reducing - for the municipality - the production cost. The interest is represented by the electoral performance in the municipality by the then- candidates for governor, - state government - whose performance is measured by the margin of victory over the runnerup candidate ${ }^{12}$. This type of spending (a form of patronage) directly by the state government, is not discriminated spatially by municipality in the state budget, which impedes its direct measurement ${ }^{13}$.

The elected executive or administration that wishes to run for re-election has different incentives for patronage measures than one with no possibility of another mandate. A dummy variable identified the governor re-elected in the 1998 election.

The inhabitants of municipalities have the option of redefining their political map by breaking away from the existing one and forming a new municipality. This was a particularly intense process in the 1990s. Constitutionally mandated transfers are approximately defined per inhabitant, so the fragmentation of a municipality does not change the joint revenue of the old and new units - transfers and the local tax base remain the same ${ }^{14}$ - nor does the population served differ. Nevertheless, the fixed costs of the local executive and legislative apparatus increase with the multiplication of municipalities. Thus, the number of them contained within a comparable minimum area can be used as an indication of these costs. Although this fragmentation into smaller units can put government in closer touch with citizens, its overall effect is an empirical question.

An important part of local budgets comes from constitutional transfers from the state and federal governments. The transfer between governments makes the relation between the public that pays taxes and that part of the public which receives the corresponding benefits more indirect, which in principle generates less social control over the manager.

The incentive for the mayor to manage local affairs better depends on the degree of institutional and social control, other institutional questions and the electoral benefit of the mayor. Institutional control can be related to the mayor's political party and can be exercised through sectorial municipal boards. These incentives were considered through five types of variables: the existence of sector boards; modernization of the public administration; a dummy for reelection of the mayor; degree of competition for mayor mandate; and the political party of the elected mayor.

\footnotetext{
12 normalized by the number of inhabitants

${ }^{13}$ This kind of relation exists for federal level too. Due to the Real Plan, votes for state and federal level were aligned, and the correlations between margins of governor and president for the 1994 and 1998 elections $(88 \%, 75 \%)$ make it difficult to identify separate effects. Therefore, we consider only governor's race margins and interpret the results as the effect of governor and president.

${ }^{14}$ The taxing powers of levels of government are constitutionally defined in Brazil. Municipal governments are authorized to levy taxes on services by firms established within their borders (or services performed within them in some cases) and on urban real estate (property taxes on rural real estate within municipal boundaries fall under federal authority).
} 
The existence of sectorial boards drawn from the target public makes management more transparent and participative and is an indicator of its quality. The modernization of public administration is related to two important transforming mechanisms: outsourcing and the computerization of services. Both are associated with the contracting of private services, seeking greater efficiency. These are complex processes, which we measured in simplified form through the number of functions in a municipality subject to each of these mechanisms.

In a system with perfect information, the re-election of the mayor is recognition of his or her good administration, and thus should be related to his or her efficiency. In the Brazilian electoral system, and given the average level of voters' education, this does not necessarily occur. Re-election of a mayor in 1996, for which we have data, refers to a term that started in 1992, and the second term ends in 2000. This covers most of our study period. We expect that municipalities where the mayor was re-elected were more efficient. The re-election for mayor mandate was only possible after 1994, therefore re-election for mayor was possible only for the 1996 election.

The intensity of the political dispute is an element that shapes the administration of public affairs and can act as an incentive to better management or to patronage, in both cases a determinant of the efficiency with which services are provided. This intensity is represented by a vote concentration index, considering the 16 parties receiving the most votes, in national terms, and measured by the sum of the squares of the party shares in the municipal elections (Herfindahl-Hirschman Index).

The electoral system in Brazil generates a lot of political parties. These characteristics at the federal level have been studied in the literature, such as Kinzo (1993) and Rodrigues (2002). But these characteristics are not necessarily the same at the municipal level, where politics is focused more on local questions (Schmtt 2000). The party effect was considered through four dummy variables, one for each of the largest parties - PMDB, PSDB, PFL ${ }^{15}$ and $\mathrm{PT}-$ which are the parties of $60 \%$ of the mayors, representing $55 \%$ of the population.

Besides these variables we also consider variables with the shape of municipality as control variables, the rate of urbanization, the age range (younger than 10 and older than 65), gender and the Gini coefficient and spatial densitiy of population.

\section{Results}

In this section we first discuss the treatment of the data, then analyze the performance of the specifications adopted, and finally examine the estimates.

\subsection{Treatment of the data}

The data set comes from a combination of four sources: $a$ ) the annual spending accounts of the municipalities, produced by the Finance Ministry (available in its Finbra system); $b$ ) the indicators that are included in the Human

\footnotetext{
${ }^{15}$ Since the data were gathered for this study, the PFL has changed its name to the "Democrats" or DEM.
} 
Development Index (HDI), mainly derived from the 1991 and 2001 Demographic Census, conducted by the Brazilian Institute of Geography and Statistics (Instituto Brasileiro de Geografia e Estatística, IBGE); c) the electoral data made available by the Superior Electoral Tribunal (Tribunal Superior Eleitoral, TSE); and d) data from the Municipal Survey (Munic), also conducted by the IBGE. A detailed description of the data is presented in the Appendix.

The number of municipalities increased from 266 in 1990 to 567 in 2000, which made the population coverage of many municipalities variable over the period. The IBGE has defined the concept of "minimum comparable area" (Área minima comparável, or AMC), which is a redefinition, stable for a certain period, of the concept of the municipality. The use of this concept has the advantage of permitting analysis of the set, but hinders interpretation because these entities are not political decision-making units. In this case, these entities should be viewed as being a "federation" of municipalities that generates the resources of the participating municipalities, whose results reflect an average of the grouped region. For this reason, we estimated the model with a version that organizes the base with AMCs and another that excludes municipalities that were grouped in AMCs.

The source of information on public spending is the Brazilian Finances database, made available by the National Treasury Secretariat (Finbra-STN), part of the Finance Ministry, for the years 1989 and 1999. The public spending per municipality is the average amount per municipality of total budget spending, deflated for the period, since data is missing for some municipalities in some years. The deflator adopted for the 1995-1999 period is the INPC (National Consumer Price Index) and that for the previous period is such that the total average spending in each year is equal to the total spending in 1994.

It is difficult to measure public expenditures in a period of high inflation $^{16}$, because the distribution during the year is not known and varies by municipality. This makes use of a price deflator inadequate. We decided to deflate our spending series by the National Consumer Price Index (INPC) for the period from 1995 on and adjusted ${ }^{17}$ for the period 1989-1995 to make the total spending of all municipalities constant. To test how much this limitation influences the results, we estimated the model in two versions: one with the average per capita spending for the complete period (1989-1999); and the other only for the period after monetary stabilization (1995-1999). O finbra foi também utilizado para calcular a proporção das receitas municipais que são transferências dos estados ou da federação.

The social indicator is derived from the calculations of the HDI for 1991 and 2000. We chose all the indicators that measure social conditions that fall under local responsibility, namely 3 health indicators, 18 educational ones (basic through secondary) and 3 indicators of the supply of public services in general.

\footnotetext{
${ }^{16}$ Brazil suffered from very high and variable inflation during the study period (peaking as high as $80 \%$ per month at times), punctuated by brief stable intervals, until the middle of 1994, when stability was finally achieved. Since then average inflation has been at single-digit yearly levels.

17. The spending is supplied in annual budgetary terms, so we do not know when the money was actually spent. Deflating this spending by the average National Consumer Price Index (INPC) produced results that were not very interpretable. With this procedure we do not have any way to identify a possible temporal trend variation of spending, but it does ensure the coherence among municipalities.
} 
Table 1: Correlation between Social Indicators $(\mathrm{S})$ and social index $(\mathrm{S} \beta)$

\begin{tabular}{|c|c|c|c|}
\hline \multicolumn{4}{|l|}{ Health Indicators } \\
\hline Life expectancy at birth & 0.56 & Probability of living to 40 & 0.49 \\
\hline $\begin{array}{l}\text { Mortality up to one year of } \\
\text { age }\end{array}$ & -0.50 & $\begin{array}{l}\text { Probability of living until } \\
60\end{array}$ & 0.57 \\
\hline $\begin{array}{l}\text { Mortality up to five years of } \\
\text { age }\end{array}$ & -0.48 & & \\
\hline \multicolumn{4}{|l|}{ Education Indicators } \\
\hline \%of 5-6-year-olds in school & 0.43 & $\begin{array}{l}\text { \%of } 15-17 \text {-year-olds with } \\
\text { fewer than } 8 \text { years of study }\end{array}$ & -0.56 \\
\hline$\%$ of $7-14$ years of schooling & 0.49 & $\begin{array}{l}\% \text { of illiterate } \\
18 \text {-24-year-olds }\end{array}$ & -0.58 \\
\hline $\begin{array}{l}\text { \%of } 10-14 \text {-year-olds in } \\
\text { school }\end{array}$ & 0.51 & $\begin{array}{l}\% \text { of } 18 \text { - } 24 \text {-year-olds with } \\
\text { fewer than } 4 \text { years of study }\end{array}$ & -0.65 \\
\hline $\begin{array}{l}\text { \%of illiterate } 7 \text { to } \\
14 \text {-year-olds }\end{array}$ & -0.48 & $\begin{array}{l}\% \text { of } 18-24 \text {-year-olds with } \\
\text { fewer than } 8 \text { years of study }\end{array}$ & -0.71 \\
\hline $\begin{array}{l}\% \text { of } 7 \text { to } 14 \text {-year-olds with } \\
\text { one year of delay }\end{array}$ & -0.54 & $\begin{array}{l}\text { \%of illiterates over } 15 \text { years } \\
\text { old }\end{array}$ & -0.71 \\
\hline $\begin{array}{l}\% \text { of illiterate } 10 \text { to } \\
14 \text {-year-olds }\end{array}$ & -0.48 & $\begin{array}{l}\text { \%of people } 25 \text { and over } \\
\text { with fewer than } 4 \text { years of } \\
\text { study }\end{array}$ & -0.80 \\
\hline $\begin{array}{l}\% \text { of } 10-14 \text {-year-olds with } \\
\text { over one year of delay }\end{array}$ & -0.54 & $\begin{array}{l}\text { \%of people } 25 \text { and over } \\
\text { with fewer than } 8 \text { years of } \\
\text { study }\end{array}$ & -0.86 \\
\hline $\begin{array}{l}\% \text { of } 10-14 \text {-year-olds with } \\
\text { fewer than } 4 \text { years of study }\end{array}$ & -0.50 & $\begin{array}{l}\text { \%of } 15 \text { to } 17 \text {-year-olds in } \\
\text { school }\end{array}$ & 0.47 \\
\hline $\begin{array}{l}\% \text { of illiterate } \\
15-17 \text {-year-olds }\end{array}$ & -0.50 & $\begin{array}{l}\% \text { of } 15 \text { to } 17 \text {-year-olds in } \\
\text { secondary school }\end{array}$ & 0.55 \\
\hline $\begin{array}{l}\text { \%of } 15-17 \text {-year-olds with } \\
\text { fewer than } 4 \text { years of study } \\
\text { Supply of Public Services }\end{array}$ & -0.55 & $\begin{array}{l}\text { Average years of study of } \\
\text { people } 25 \text { and over }\end{array}$ & 0.73 \\
\hline $\begin{array}{l}\% \text { of people living in } \\
\text { dwellings with piped water }\end{array}$ & 0.49 & $\begin{array}{l}\% \text { of people who live in } \\
\text { urban with trash collection } \\
\text { service }\end{array}$ & 0.36 \\
\hline $\begin{array}{l}\% \text { of people living in } \\
\text { dwellings with electricity }\end{array}$ & 0.54 & & \\
\hline
\end{tabular}


Table 2: Descriptive Statistics of $(\mathrm{x}, \mathrm{z})$ variables

\begin{tabular}{lcc}
\hline Variable & mean & Std.dev \\
\hline Log of the municipality's population in 1991 & 9.48 & 1.09 \\
Number of municipalities in the AMC & 1.29 & 1.12 \\
Victory margin of the governor elected in 1994 & 0.09 & 0.09 \\
Victory margin of the governor elected in 1998 & 0.11 & 0.11 \\
Dummy for the second mandate in 98 state election & 0.40 & 0.49 \\
Total transfers/total revenue of the municipality & 0.46 & 0.23 \\
Number of computerized functions & 7.76 & 2.32 \\
Number of outsouced functions & 3.37 & 2.59 \\
1 if the mayor was reelected in 1996 & 0.25 & 0.41 \\
Degree of concentration in the 1996 race for mayor & 5.17 & 1.71 \\
1 if the party of the mayor elected in 1996 was the PT & 0.02 & 0.13 \\
1 if the party of the mayor elected in 1996 was the PSDB & 0.18 & 0.37 \\
1 if the party of the mayor elected in 1996 was the & 0.24 & 0.41 \\
PMDB & & \\
1 if the party of the mayor elected in 1996 was the PFL & 0.17 & 0.36 \\
Existence of an education advisory board in 1998 & 0.75 & 0.42 \\
Existence of a health board in 1998 & 0.98 & 0.14 \\
Existence of social assistance advisory board in 1998 & 0.93 & 0.24 \\
\hline Source
\end{tabular}

Source: authors calculation

Table 2 shows the list of the indicators utilized, and as an example, the correlation between the quantity $S \beta$ estimated in one of the models and each of the social indicators, and shows that the correlation is positive with each of the indicators whose increase indicates an improvement in conditions, and negative with the rest. The quantity $S \beta$ is a linear combination of $S$, and can be interpreted as a synthetic indicator of the social conditions.

The source of electoral variables is the TSE files and consider votes for governor in the 1994 and 1998 elections, votes for mayor in the 1996 election, and identification of governor and mayors in the second mandate. The variables are:

- Margin of victory over the runner-up candidate measured by the difference in each municipality between the votes of the elected governor and the votes of the runner-up candidate for the 1994 and 1998 elections;

- Dummy indicating whether the governor was re-elected in 1998

- Degree of concentration of the votes received by the parties: sum of the squares of the party shares in the local election in 1996;

- Dummies indicating the mayor's party;

- Dummy indicating whether the mayor was re-elected in 1996

The control Variables are: 1) density: total population/municipal surface; 2) rural inhabitants/total; 3) aged under 10/total; 4) aged over 65/total; 5) women/total, 6) scale: $\log$ of the population. 
Table 3: Inforamtion Criteria

\begin{tabular}{|c|c|c|c|c|c|c|}
\hline \multicolumn{7}{|c|}{ Original Scale } \\
\hline & \multicolumn{3}{|c|}{ Homo } & \multicolumn{3}{|c|}{ Hetero } \\
\hline & aic & bic & $\mathrm{Hq}$ & Aic & bic & hq \\
\hline $\mathrm{S} 1, \mathrm{~s} 0$ & 0.205 & 0.331 & 0.250 & 0.164 & 0.290 & 0.209 \\
\hline $\mathrm{S} 1+\mathrm{s} 0$ & 0.241 & 0.322 & 0.269 & 0.199 & 0.280 & 0.227 \\
\hline S1-s0 & 0.415 & 0.496 & 0.443 & 0.374 & 0.455 & 0.403 \\
\hline \multicolumn{7}{|c|}{ Spatial Dif $(\Delta w)$} \\
\hline & \multicolumn{3}{|c|}{ Homo } & \multicolumn{3}{|c|}{ Hetero } \\
\hline & aic & bic & $\mathrm{Hq}$ & Aic & bic & hq \\
\hline $\mathrm{S} 1, \mathrm{~s} 0$ & 0.114 & 0.240 & 0.158 & 0.112 & 0.239 & 0.157 \\
\hline $\mathrm{S} 1+\mathrm{s} 0$ & 0.123 & 0.204 & 0.151 & 0.122 & 0.203 & 0.151 \\
\hline S1-s0 & 0.265 & 0.346 & 0.294 & 0.262 & 0.343 & 0.290 \\
\hline
\end{tabular}

\subsection{Specifications}

The estimate of the inefficiency of municipal management and the effect of the explanatory variables depends on three questions: 1) the form of insertion of the efficiency determinants, equations (1) and (2); 2) the form of the allocation function of the social indicators: variation, level or unrestricted form; 3 ) the choice of the information set - the effect of considering only the nonfragmented municipalities - and the measure of public spending; and finally 4)the results can be obtained with or without correction for omitted variables. This makes a total of 36 models.

To simplify matters, we present the performance criteria for the case using the expenditures over the entire decade and without restriction to nonfragmented municipalities. This gives us 12 models with the same dependent variable. This means that we can choose the specification that most closely adheres to the data using the standard information criteria in the econometrics literature, namely: AIC, BIC and $\mathrm{HQ}^{18}$. Table 3 present these results.

In the model estimated with the variables in the original scale, the best specification according to the criteria (aic,hq) is the heterogeneous model with the social variables in unrestricted form $(s 1, s 0)$. In the case of the variables transformed with the operator $\left(\Delta^{w}\right)$, the best model, according to the criteria (bic, hq) is the heterogeneous model with the social variables in level $(s 1+s 0)$.

In all cases, the algorithm estimated an asymmetric term identified with a variance significantly different than zero, which indicates that the unobservable component that measures the distance from the frontier does not have a spatial trend. In this case with the variables transformed by the operator $\left(\Delta^{w}\right)$, this component corresponds to the deviation of the distance from the frontier and the results indicate that the asymmetry property is preserved for this transformation.

\footnotetext{
18. Respectively, Akaike's information criterion, Bayesian information criterion and the Hanna-Quim criterion (see Lütkepohl (1991).
} 


\subsection{Estimates}

The estimates are presented for the coefficients of the variables that explain the cost of supplying the service and the determinants of inefficiency. For both cases the table shows the results of the three information sets: spending in the entire decade (c90), spending in the second five years (c95), and spending in the decade limited to the non-fragmented AMCs (c89x), this is combined with the $(\mathrm{c} 90, \mathrm{c} 95)$ cases for the model with the variables transformed by the operator $(\Delta \mathrm{w})^{19}$ that mitigate the effect of non observed variables.

The results obtained with the best model for data in original scale and transformed by the operator $(\Delta \mathrm{w})$ are organized in tables 4 and 5 according to the type of determinant. To evaluate the robustness of these results we estimated the model $g \mid S, x, z$ using OLS and robust standard errors, and obtained, qualitatively, the same results. To simplify matters, we omitted the coefficients of the social indicators and control variables and coefficients not significant at the $10 \%$ level.

Table 4 shows that all coefficients are significant (1\%) for all versions estimated, except the coefficient related to federal transfers, which is not significant for the c95 case. The results are almost the same for all versions, despite the criticism of the low quality of data before 1995 and of the effect of aggregation of municipalities in AMC.

An increase of scale and a decrease in fragmentation reduce the spending required to obtain the same amount of social result. The governors have the option of allocating in discretionary form a fraction of the public expenditures under their control, and thus can do so as a way to satisfy collective interests or according to electoral logic. These expenditures are not observed, but we can observe the result of this action in terms of votes. The results show a patronage relationship between the governor candidate and his or her base constituencies for governor candidate in 1994 and 1998. This evidence indicates that the greater the loss margin of the elected governor in the municipality, the lower that municipality's spending, which can indicate the existence of focused and direct expenditures of the state government in the area of education and health.

In the 1994 election there was no possibility of re-election, so all the candidates were new entrants, unlike the 1998 election. The dummy variable indicates the municipalities located in states where the governor was re-elected. The result shows that the governor's re-election implies higher spending for the same social state, suggesting that a second-term governor exercises less cronyism than a first-term one, who stil has a chance of re-election.

For the first information set, spending over the whole decade (c90, c90x de-c90), the higher proportion of municipal revenue received as transfers implies increased spending for the same social result. These resources come from the state or federal treasury and are monitored by the respective audit tribunals. The fact that this variable is significant when we consider the entire decade but not for the end of the decade can be related to the more efficient monitoring of these expenditures at the end of the decade.

Table 5 shows that the significance of the coefficients depends on the version. Only the effect of the number of computerized and outsourced functions is significant at the $1 \%$ level for all the cases studied. This is an unexpected

\footnotetext{
${ }^{19}$ The algorithm do not get convergence for the $c 90 \mathrm{x}$ in this case.
} 
Table 4: Effect on Spending

\begin{tabular}{|c|c|c|c|c|c|}
\hline \multirow{2}{*}{ Sample } & \multicolumn{3}{|c|}{ Level } & \multicolumn{2}{|c|}{ Spatial dif } \\
\hline & c90 & c95 & c90x & c90 & c95 \\
\hline $\begin{array}{l}\text { Log of the municipality's } \\
\text { population in } 1991\end{array}$ & -0.33 & -0.30 & -0.35 & -0.31 & -0.31 \\
\hline $\begin{array}{l}\text { Number of municipalities in the } \\
\text { AMC }\end{array}$ & 0.05 & 0.05 & & 0.05 & 0.06 \\
\hline $\begin{array}{l}\text { Victory margin of the governor } \\
\text { elected in } 1994\end{array}$ & 0.42 & 0.41 & 0.38 & 0.35 & 0.36 \\
\hline $\begin{array}{l}\text { Victory margin of the governor } \\
\text { elected in } 1998\end{array}$ & 0.24 & 0.29 & 0.27 & 0.34 & 0.34 \\
\hline $\begin{array}{l}\text { Dummy for the second mandate } \\
\text { in } 98 \text { state election }\end{array}$ & 0.13 & 0.15 & 0.13 & 0.16 & 0.15 \\
\hline $\begin{array}{l}\text { Total transfers/total revenue of } \\
\text { the municipality }\end{array}$ & 0.24 & - & 0.22 & 0.28 & - \\
\hline
\end{tabular}

result. The inefficiency increases when the number of computerized and outsourced functions is higher. In other words, more computerized and delegated management does not generate productive gains or increase the level of transparency and control enough to make it more efficient. Thus words, these gains do not offset the cost incurred to adopt these practices.

The effect of the dummy variable for a reelected mayor is significant for most of the cases, indicating a correlation with the reduction of inefficiency. The other variables are related to local politics. The degree of concentration of voters in the race for mayor and political party of the elected mayor and the relations with the existence of citizens' boards are not significant for the spatial difference regression. These effects are not robust. This suggests that these variables are not related to better management, implying an asymmetry of information in the local political market.

\section{Conclusion}

The quality of life represented by the population's state of health and education - largely atributes of municipal responsibility - can be characterized by social indicators obtained from census data, and are multiple-interdependent attributes. Municipal administration can be viewed as a productive unit that uses a technology that associates expenditures with welfare and is represented by a production possibility frontier. The distance of each municipality from this frontier is a measure of the inefficiency of its administration.

The transformation of spending into public services that conditions the state of education and health is a complex and slow process, which depends on the volume of expenditures, the conditioning factors of the production cost and the inefficiency with which these expenditures are made. This inefficiency, in turn, depends on the relation between the benefit obtained by the manager and the cost of his or her effort. Therefore, the heterogeneity of the inefficiency among municipalities can be explained both by the incentives the 
Table 5: Explaining Inefficiency

\begin{tabular}{|c|c|c|c|c|c|}
\hline & \multicolumn{3}{|c|}{ Level } & \multicolumn{2}{|c|}{ Spatial dif } \\
\hline & c90 & c95 & c90x & c90 & c95 \\
\hline $\begin{array}{l}\text { Number of computerized } \\
\text { functions }\end{array}$ & 0.16 & 0.15 & 0.16 & 0.08 & 0.10 \\
\hline $\begin{array}{l}\text { Number of outsoucer } \\
\text { functions }\end{array}$ & 0.17 & 0.17 & 0.16 & 0.10 & 0.11 \\
\hline $\begin{array}{l}1 \text { if the mayor was reelected } \\
\text { in } 1996\end{array}$ & $-0.15^{b}$ & $-0.15^{b}$ & - & -0.22 & $-0.17^{a}$ \\
\hline $\begin{array}{l}\text { Degree of concentration in } \\
\text { the } 1996 \text { race for mayor }\end{array}$ & - & - & - & - & - \\
\hline $\begin{array}{l}1 \text { if the party of the mayor } \\
\text { elected in } 1996 \text { was the PT }\end{array}$ & $0.54^{b}$ & - & $0.64^{a}$ & - & - \\
\hline $\begin{array}{l}1 \text { if the party of the mayor } \\
\text { elected in } 1996 \text { was the } \\
\text { PSDB }\end{array}$ & - & - & - & - & - \\
\hline $\begin{array}{l}1 \text { if the party of the mayor } \\
\text { elected in } 1996 \text { was the } \\
\text { PMDB }\end{array}$ & $-0.30^{a}$ & - & $-0.29^{a}$ & - & - \\
\hline $\begin{array}{l}1 \text { if the party of the mayor } \\
\text { elected in } 1996 \text { was the PFL }\end{array}$ & - & - & - & - & - \\
\hline $\begin{array}{l}\text { Existence of an education } \\
\text { advisory board in } 1998\end{array}$ & - & $-0.21^{b}$ & - & - & - \\
\hline $\begin{array}{l}\text { Existence of a health board } \\
\text { in } 1998\end{array}$ & - & - & - & - & - \\
\hline $\begin{array}{l}\text { Existence of social assistance } \\
\text { advisory board in } 1998\end{array}$ & $-0.34^{b}$ & - & - & - & - \\
\hline
\end{tabular}

Coefficient Significant for $1 \%$

${ }^{a}$ Coefficient Significant for $5 \%$

${ }^{a}$ Coefficient Significant for $10 \%$

public administrator perceives to endeavour to be more efficient and by the local supply conditions that alter the marginal cost of this effort.

This study related the observed production cost of municipal service with measures of the final aim of this service in order to obtain a substantive measure of the efficiency of municipal public service and to evaluate whether political patronage and other political economy measures affect this result.

The model adopted estimates a production possibility frontier that relates a measure of the state of the population, to the per capita spending in conditional form to the cost of supplying the service and the incentives for efficient spending. In order to mitigate the effect of omitted variables the model uses spatial trend differences.

We estimated various specifications for this model using different measures of spending, ways to measure the effect on the population's state, and criteria to identify inefficiency an approach that mitigates the effect of omitted variables that are stable in the spatial dimension. Our results were the same for nearly all the specifications. The most robust ones indicate that: 1) the greater the size of the total population the lower will be the per capita spending to obtain similar performance results in the social indicators chosen; 2) 
the dismemberment of municipalities increased this spending and that there is an indication that governors reward their municipal voters with higher discretionary spending; 3 ) the margin of votes for a governor race has an effect on allocation of state spend between municipalities; 4) the efficiency is decreased by greater computerization or outsourcing of services; and finally 5) the existence of local advisory boards and political competition in the mayoral race did not affect the level of efficiency of local management.

In sum, the size of the spending needed to attain a certain level of quality is associated with some characteristics of municipalities, scale, municipal fragmentation and patronage of an elected governor. The fact that the local political variables were not significant, on the other hand, evidences the existence of information asymmetry in the local electoral process.

Although the results are suggestive for the understanding of municipal political economies, they must be taken with caution because with this type of data we can only measure non-causal effects, and because the observed political and institutional variables only covered the last half of the decade under study a limitation that could only be corrected with a broader data set.

\section{Bibliography}

Afonso, A. \& Aubyn, M. S. (2005), 'Non parametric approaches to education and health efficiency in oecd countries', Journal of Applied Economics 8, 227246.

Afonso, A., Schuknecht, L. \& Tanzi, V. (2005), 'Public sector esfficiency: an international comparison', Public Choice 123, 321-347.

Alston, L., Melo, M., Meuller, B. \& Pereira, C. (2007), The choices governors made: political institutions and economic performance at the sub-national level in brazil., Technical report, IPEA.

Atkinson, A. B. \& Stiglitz, J. E. (1980), Lectures on Public Economics, McGraw Hill.

Besley, T. \& Ghatak, M. (2003), Incentives, choices and accountability in the provision of public services, Technical report, Institute for Fisical Studies.

Burgess, S. \& Metcalfe, P. (1999), The use of incentive schemes in the public and private sectors: evidence from british establishments, Technical report, CMPO.

Coelli, T. A. (1996), A guide to deap version 2.1, Technical report, University of New England-Armindale.

Cutler, D. M., Elmendorf, D. W. \& Zeckhauser, R. J. (1993), 'Demographic influences on local public education expenditure: a review of econometric evidence.', Public Finance 48, 178-198.

Dixit, A. K. (1996), The making of economic policy: a transaction-cost politics perspective, MIT Press.

Dixit, A. K. (2002), 'Incentives and organizations in the public sector: an interpretive review', Journal of Human Resources 37, 696-772. 
Estache, A., Gonzalez, M. \& Trujillo, L. (2007), Government expenditures on education, health, and infrastructure: a naive look at levels, outcomes, and efficiency., Technical report, World Bank Policy Research.

Keefer, P. \& Khemani, S. (2005), 'Democracy, public expenditures, and the poor: understanding political incentives for providing public services', The World Bank Research Observer 20, 1-27.

Kinzo, M. D. G. (1993), Radiografia do quadro partidário brasileiro., Technical report, Fundação Konrad Adenauer.

Lake, D. A. \& Baum, M. A. (2001), 'The invisible hand of democracy: political control and the provision of public services', Comparative Political Studies $34,587-621$.

Lütkepohl, H. (1991), Introduction to multiple time series analysis, SpringerVerlag.

Meltzer, A. \& Richard, S. (1981), 'A rational theory of the size of government', Journal of Political Economy 89, 914-927.

Rodrigues, L. M. (2002), Partidos, ideologias e composição social: eum estudo das bancadas partidárias na Câmara dos Deputados, Editora Edusp.

Schmtt, R. (2000), Partidos politicos no Brasil (1945-2000), Editora Zahar.

Strömberg, D. (2006), Demography, voting, and public expenditures: theory and evidence from swedish municipalities, Technical report, IIES. 